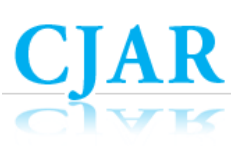

Canadian Journal of Action Research Volume 21, Issue 3, 2021, pages 52-71

\title{
SAFETY MAPPING: AN INDIGENIST APPROACH TO ACTION RESEARCH
}

\author{
Chay Brown \\ Australian National University
}

\begin{abstract}
Aboriginal people in Alice Springs mapped the safe places in their Town Camps. This participatory research led to the implementation of safety features. Safety mapping was developed in response to deficit-based research which pathologized Aboriginal people in Alice Springs. Safety mapping was conducted with Aboriginal people in Town Camps to identify safe places and improve safety. A strengths-based approach showed that problems and their solutions are known, and there are considerable safety assets within Town Camps. The safety mapping centred the voices and experiences of Aboriginal people to produce research that was of benefit to Town Campers, over which Indigenous people retained ownership. This paper highlights that an Indigenist approach to participatory action research is strengthened by Indigenous knowledge in driving social justice.
\end{abstract}

KEY WoRDS: Indigenist participatory action research; Indigenous knowledge; Safety mapping; Strengths-based approach

\section{INTRODUCTION}

Indigenist methodology is about 'writing back' against deficit-based research that problematizes Indigenous people (Aveling, 2013; Smith, 1999). The convergence between participatory action research and Indigenist methodology allows Indigenous people to set their own research agenda and be empowered with knowledge products that can further their priorities. Safety mapping was developed in response to deficit-based methods and reporting which attempted to map crime hot spots in the town of Mparntwe ${ }^{1 / A l i c e ~ S p r i n g s, ~}$

\footnotetext{
${ }^{1}$ Mparntwe is the traditional Arrernte name for the town of Alice Springs. The Arrernte people are the Indigenous people and traditional custodians of the land Alice Springs has been built upon. Arrernte people have cared for country in Central Australia for thousands of years.
} 
a small regional town in Australia's Northern Territory which has the highest rates of violent crime in Australia (Criminal Justice Research and Statistics Unit, 2017; Department of Attorney-General and Justice , 2018). Safety mapping flipped this concept to work with Aboriginal people from Town Camps (Town Campers) to identify the safety issues and discuss the safe places in their communities with the aim of identifying ingredients of safety in the hope they could be replicated to increase Town Campers' feelings of safety. The safety mapping offered a culturally safe way of harnessing Town Campers expertise about safety issues and developing solutions to these issues.

In keeping with Indigenist methodology, it is necessary that I begin by self-identifying and stating my positionality. I am a white non-Indigenous woman who was born in Mparntwe/Alice Springs and raised on a cattle station near the community of Jay Creek. My lived experience motivates much of my research on domestic, family, and sexual violence. I grew up in a violent home and was eventually placed in foster care. I have witnessed violence against women just about every day of my life. I also grew up in and around Town Camps and remote Aboriginal communities, and I have many relationships and connections there. I particularly have connection to Warlpiri people through my mother and her connections, so there I am called Nampijinpa. I am also proud to have connection to Arrernte and Anmatyerre people through my friends and family. I have been privileged to be able to draw upon my connections and relationships with Indigenous people to guide me throughout my research.

This paper will first explain the history and context of Town Camps in Mparntwe/Alice Springs and outline the safety mapping method before explaining how safety mapping illustrates the strength of an Indigenist approach to action research. It will then present the findings from the safety mapping.

\section{CONTEXT}

The safety mapping took place in Town Camps in Mparntwe/Alice Springs. Town Camps are Aboriginal communities on the fringes of Alice Springs. Town Camps have a long history of being traditional camping sites of Aboriginal people, but Aboriginal people became settled in these places through the impacts of colonisation (Foster, Mitchell, Ulrik, \& Williams, 2005). Many Aboriginal people in Central Australia were pushed off their traditional lands by pastoralists, and moved to Town Camps where rations were distributed (Foster, Mitchell, Ulrik, \& Williams, 2005). Aboriginal people also came to reside in Town Camps after mass firings of Aboriginal stockmen after equal wages were legislated in the 1960s (Foster, Mitchell, Ulrik, \& Williams, 2005). Many Aboriginal people also moved to Town Camps to be closer to their children who had been removed as part of the stolen generation ${ }^{2}$ and were living in the Bungalow ${ }^{3}$ (Foster, Mitchell, Ulrik, \& Williams, 2005). These as well as other factors meant that Town Camps became increasingly permanent. However, for a long time, the government saw Town Camps as informal impermanent settlements, and there were several attempts at forced removal of Aboriginal people to outlying missions (Tangentyere

\footnotetext{
2 The stolen generation was the forced removal of Aboriginal and Torres Strait Islander children from their families by Australian governments and church missions between 1910 and 1970.

${ }^{3} \mathrm{An}$ institution for Aboriginal children who had been removed from their families. The Bungalow was located at the Telegraph Station in Alice Springs.
} 
Council, 2008). Throughout many of these years, most people on Town Camps lived in humpies or tin sheds, the town of Alice Springs was declared a prohibited zone for Aboriginal people, and a pass system was implemented to control the movement of Aboriginal people in the town (Foster, Mitchell, Ulrik, \& Williams, 2005; Tangentyere Council, 2008).

In 1979, Tangentyere Council was formed, comprised of representatives from the Town Camps (Tangentyere Council, 2008). Tangentyere Council began advocating for Town Campers and in 1981, began winning leases and forming Housing Associations (Tangentyere Council, 2008). Town Campers began campaigning for their right to basic services and infrastructure, however, Town Camps have continued to be subjected to periodic government neglect and intervention.

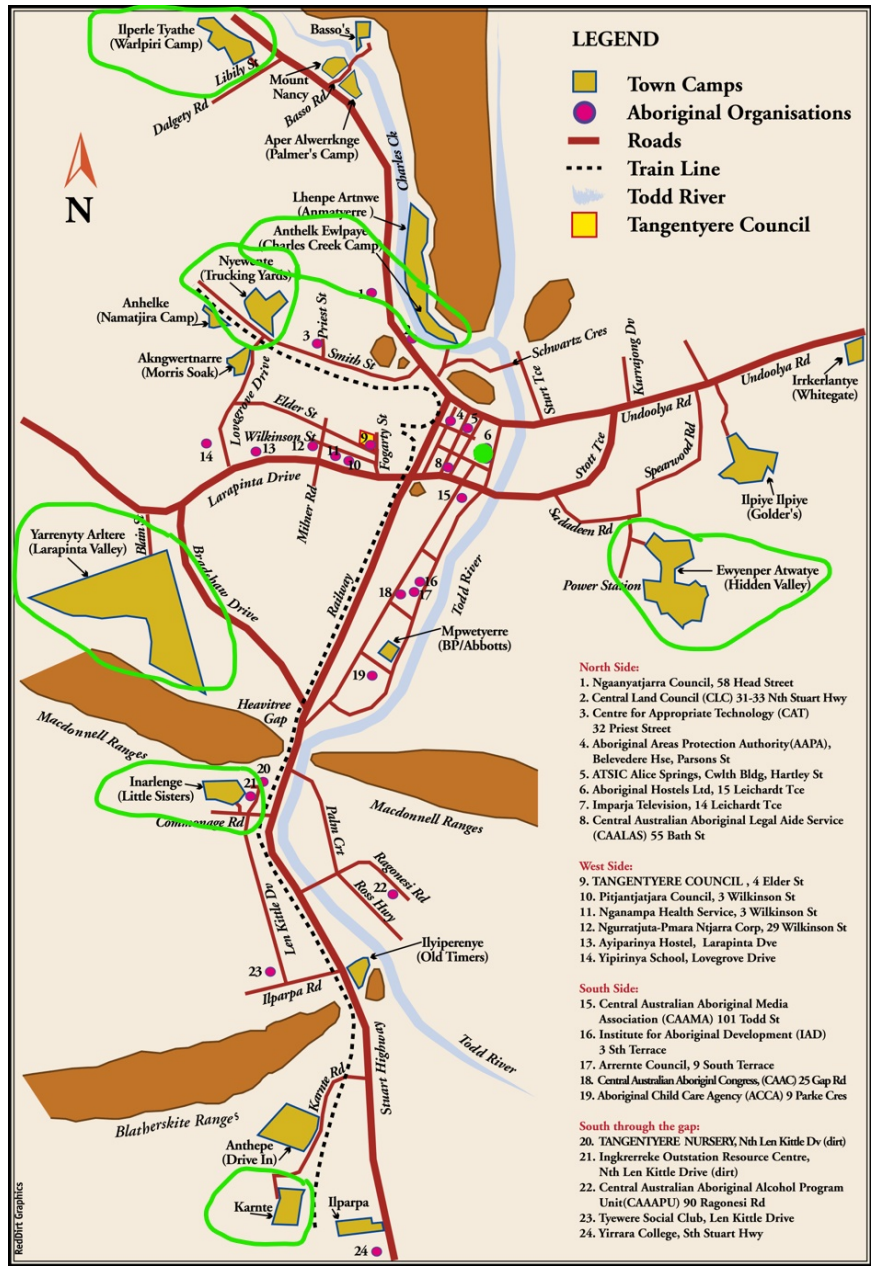

Figure 1. Map of Alice Springs showing the location of Town Camps (from TCAC, 2005)

As a result of this history, Town Camps have become characterised by poor infrastructure and lack of services. Town Camps continue to have inadequate housing, with high rates of overcrowding, and high rates of disadvantage, inequality and poverty. However, Town Camps are also incredibly strong communities, evidenced in their relationships and survival. Town Campers have a unique and strong identity as 'Town Campers' and sense of pride in Town Camps and their shared history. Town Camps are culturally and linguistically rich, with more than five Indigenous languages and cultures being spoken and practised. Town 
Camps demonstrate their strength through resilience, self-determination, and connection to country.

There are 16 Town Camps in Mparntwe/Alice Springs, which are located on the fringes of the township. Figure 1 was created by Tangentyere Council, and the gold areas indicate the locations of the Town Camps. This map still shows the original 18-19 Town Camps (some people considered one of the camps to be two different camps), but Whitegate has since been forcibly shutdown and Ilpiye Ilpiye has signed a separate service agreement with Alice Springs Town Council, meaning it is technically no longer a Town Camp. In Figure 1, the Town Camps circled in green indicate the Town Camps where the safety mapping sessions took place, and the single green dot shows the place where the safety mapping with a representative group took place.

Currently, the 16 remaining Town Camps exist in jurisdictional limbo. While Tangentyere Council acts as their advocacy body, it is unclear whose responsibility it is to provide services and infrastructure to Town Camps: Alice Springs Town Council, the Northern Territory government, or the Federal government. This confusion means that Town Camps continue to lack basic services and facilities. At present, not a single Town Camp meets the minimum guidelines for subdivisions within Alice Springs (Brown, 2019). This is a source of great frustration for Town Campers who have been campaigning for improved and adequate services and infrastructure for some time. It is within this context that the safety mapping took place.

\section{METHOD}

Safety mapping is a strength-based way of engaging and working with Town Campers to identify safety issues and their solutions. Safety Mapping was developed in response to a method that attempted to map crime hotspots by using data from mobile CCTV stations. The findings were then used to inform policy and policing. However, as I am from Mparntwe/Alice Springs and know this place well, I disagreed that the hot spots were necessarily unsafe or dangerous, and in fact considered that they may be places of safety as people were able to call for help in these locations.

At the time the CCTV research was released, I was undertaking my $\mathrm{PhD}$ research investigating what works to prevent violence against women in the Northern Territory. As part of this research, I was working alongside a group of senior Aboriginal women from Town Camps called the Tangentyere Women's Family Safety Group (TWFSG). I discussed the CCTV research with TWFSG, and they agreed that the crime 'hot spots' were not necessarily unsafe, but rather Aboriginal people were making use of the CCTV and emergency buttons in these locations to make their own safety. TWFSG felt that the only true way to identify places that were dangerous or safe was to include and listen to Aboriginal people in the research. TWFSG knew that a strengths-based approach could harness Indigenous knowledge and yield far greater insight into safety. As a result of this discussion, the safety mapping method was developed and TWFSG invited me to undertake this research in partnership with Town Campers. 
The method of safety mapping was designed to work with community members in a participatory process to identify the safe places, rather than places of danger. The safety mapping took place in eight focus groups: seven were held in community centres on Town Camps, and one was held in the Alice Springs town with TWFSG. Safety mapping sessions were conducted at Karnte, Hidden Valley, Larapinta Valley, Charles Creek, Trucking Yards, Little Sisters and Warlpiri Town Camps. Participants were recruited through the community centres on Town Camps. These are places where Town Campers often come to have meetings, to paint, and to engage with services. These are relaxed, informal, and familiar places, and therefore, culturally safe environments. I contacted the community centres using TWFSG's connections and discussed the safety mapping with them. The community centre staff then discussed the safety mapping with Town Campers to seek their permission and engagement. If they agreed, a time was made for the focus group and anyone who was interested could attend and participate as much or as little as they liked.

Some of the safety mapping sessions were larger than others, which explains the disparity in the participants from each participating Town Camp, as shown in Figure 2. The TWFSG women live in different Town Camps. One woman who previously lived at Basso's Camp for years now lives in what is referred to as 'Urban', which means public housing within an Alice Springs suburb. The participants listed as residing in 'Alice Springs' comprise nonIndigenous staff who attended the safety mapping, all of whom live within Alice Springs suburbs. As can been seen in Figure 2,11 out of the 16 Town Camps were represented in the safety mapping.

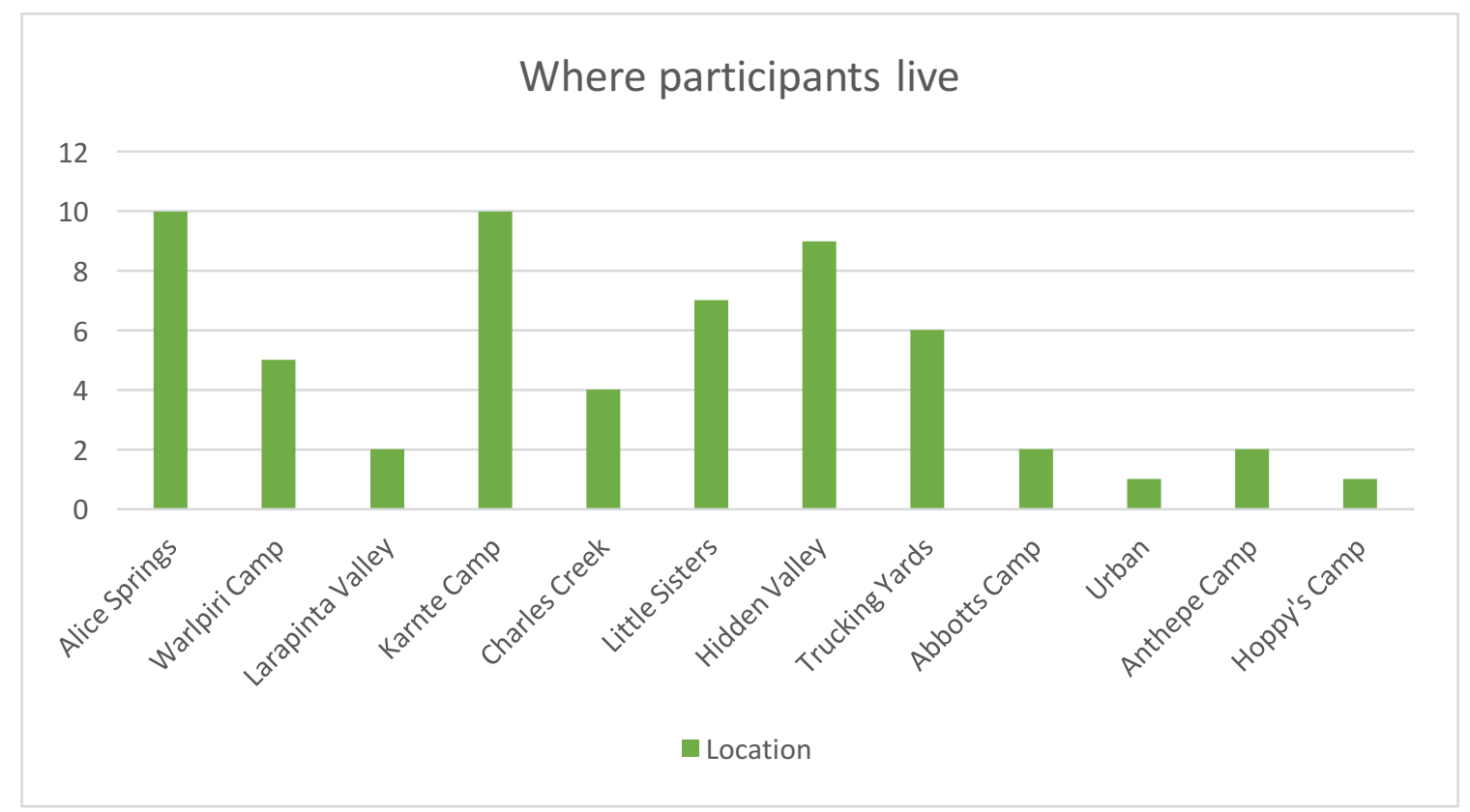

Figure 2. Breakdown of where participants reside.

As part of ensuring the safety mapping session was culturally safe, the method was designed in partnership with TWFSG and community centre staff. To be culturally safe, it was important that the method was strengths-based, emphasised listening (and not asking 
too many questions which is considered culturally inappropriate), used plain language and was undertaken in a relaxed environment. Therefore, the safety mapping began by sharing food and took place outside, usually sitting in a circle on the ground, or at tables as participants painted. The safety mapping included some planned questions ${ }^{4}$, but the semistructured format gave me the flexibility to ask follow-up questions and to focus on listening to what Town Campers felt was most important when it comes to creating safety.

Each safety mapping participant was given a map of their town camp and was asked to circle the safe places. Each participant then shared the places they had circled, and explained why they had selected them. Many participants chose to label their maps and update them to include recently built houses and informal roads. Figure 3, for example, shows a participant's map of Hoppy's Camp, they have highlighted safe places in green and they have labelled existing pay phones. This participant has written that a safe place is "where to go to for help". They have also bullet pointed that regular community meetings and accessible working pay phones are needed for safety.

WHERE TO GO TO FOR HEL:

\section{Hoppy's Camp}

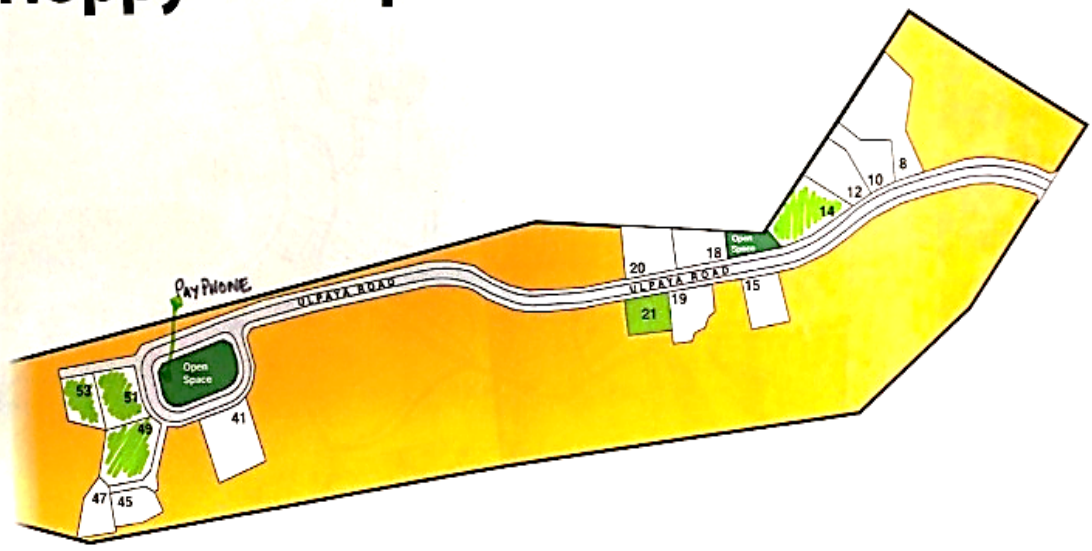

Figure 3. Edited map of Hoppy's Camp

Many participants also added safety features to their maps that they wanted to see in their Town Camps. Figure 4, for example, shows how a participant from Little Sisters Town Camp edited their map to show informal side roads, where they would like to see gates or fences put in, and the houses where 'cheeky dogs'5 are a problem.

\footnotetext{
4 There were four planned questions, which were developed in partnership with TWFSG and community centre staff. These questions were: Can you tell me about your community? What does 'safety' mean to you? Using the map, can you circle the safe places, and what makes these places safe? If we are ever unsafe, where would you go or who would you talk to?

${ }^{5}$ Cheeky dogs are aggressive stray or camp dogs that are likely to bite, and have long been a problem on many Town Camps. Dog attacks are frequent and often severe on Town Camps.
} 


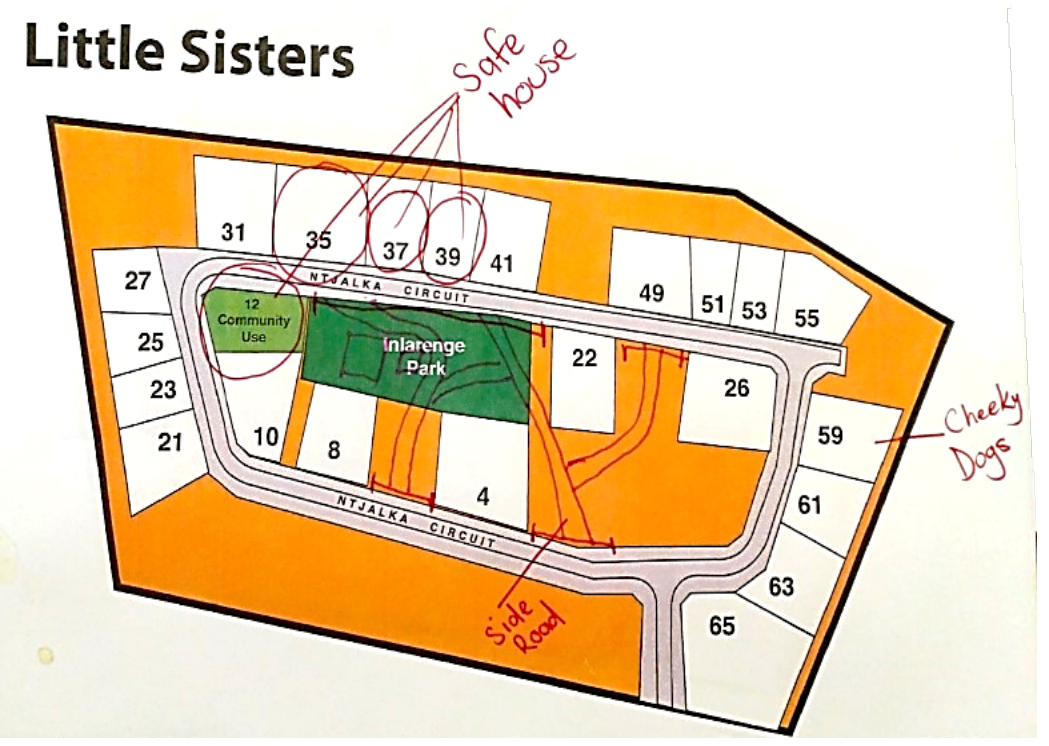

Figure 4. A map edited during the safety mapping session by a participant from Little Sisters

In Figure 5, the participant has drawn dots along the roads and labelled them 'rocks' - this participant felt bollards should be placed along the roads to prevent the use of informal roads in and out of the camp which they felt jeopardised the safety of Town Campers, particularly young children. This participant also labelled the locations of payphones and added fences around the open spaces.

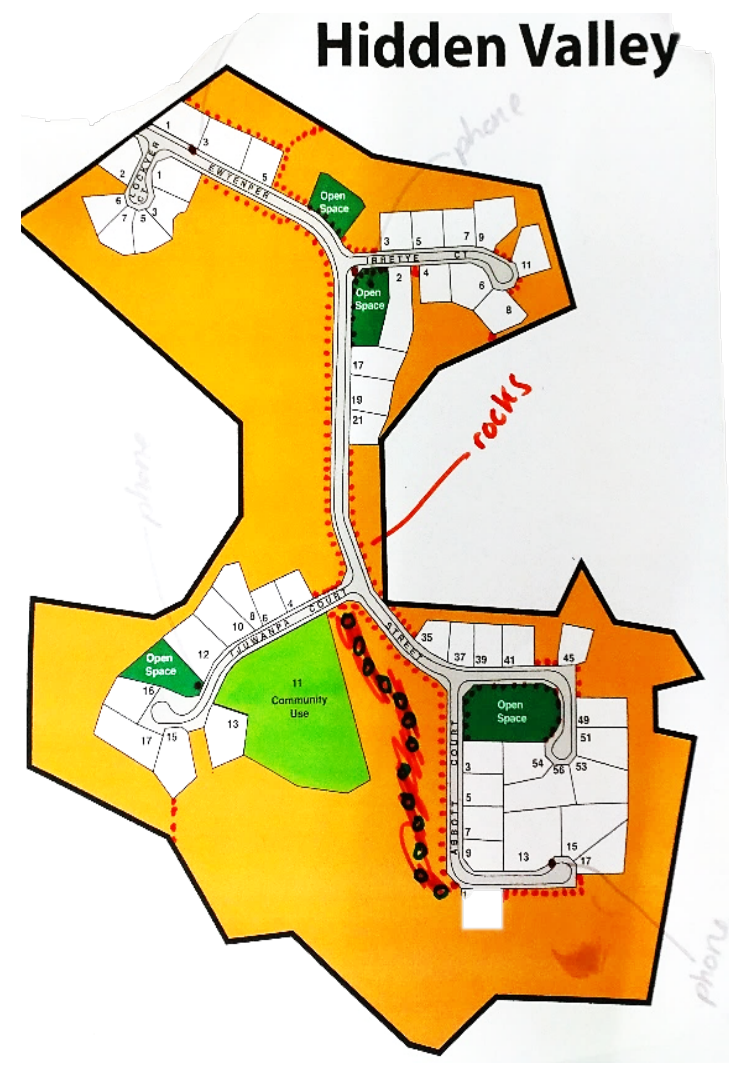

Figure 5. A participant's edited map of Hidden Valley Camp 
Other participants simply used their map as a reference in their discussions, and would gesture or point to certain areas as they expressed their ideas. Many Town Campers have limited English, so the maps were helpful as they provided each participant with a means to take part and share their views, without having to rely solely on English. Most participants had never seen a map of their Town Camp before, and many asked to keep their map, indicating a high level of engagement. Many participants commented that they had found the safety mapping useful and that "it was good to talk about safety" [SM37] and "you can come again [to do the safety mapping]" [SM5].

The safety mapping with TWFSG built upon our existing relationship, so additional questions were asked. In addition to the mapping exercise, the participants were also asked to draw their safe place. Each woman then explained their artwork and the safety features they had drawn. The drawings were similar, and usually depicted houses with fences and lighting, where women could safely take care of their children. Figure 6, for example, shows a grandmother with grandchildren and dogs standing in front of a house. The house has a fence, garden, doors and windows, and has lights on inside.

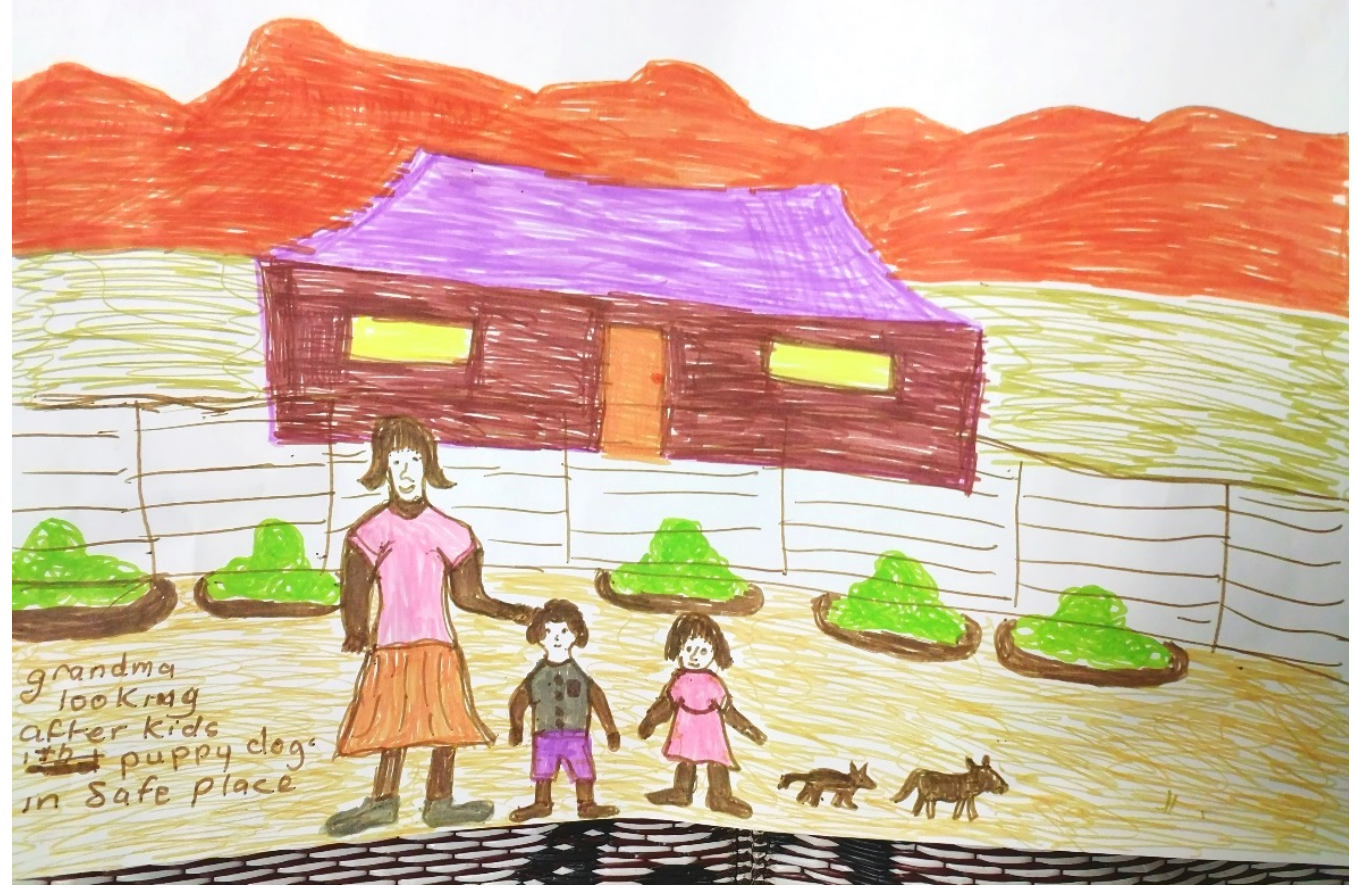

Figure 6. A participant's drawing of their idea of a safe place

Similarly, Figure 7 shows a house in the Town Camp surrounded by a high fence and lots of lighting. There is a children's playground and secure parking. The road in is lined by trees, and there is a gate. Many of these features may seem obvious or everyday to outsiders, but Town Camps houses are often dilapidated and overcrowded. 


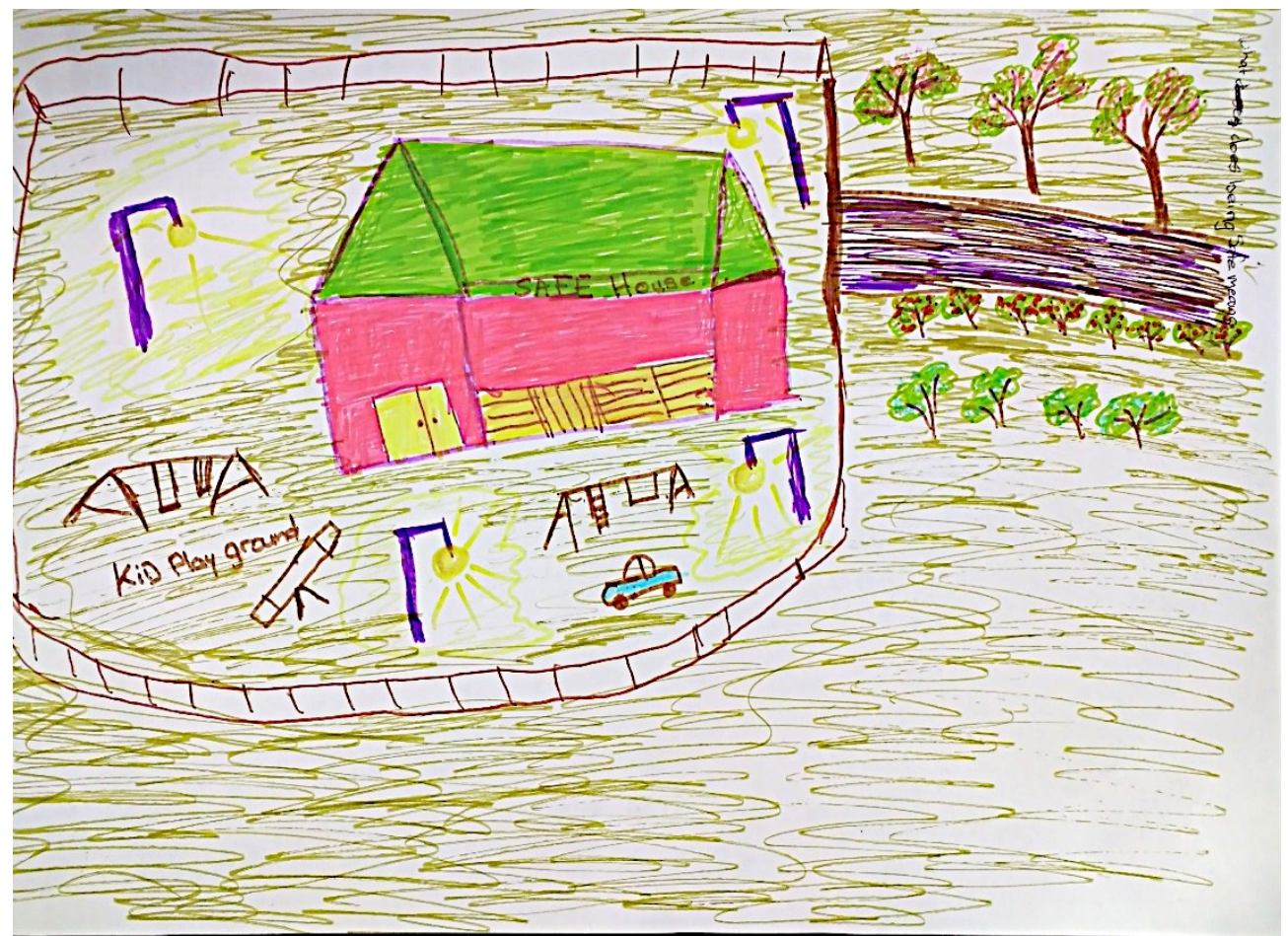

Figure 7. A participant's drawing of a safe house.

Other depictions of safe places showed entire Town Camps, but included fenced yards, lighting, gardens, and properly demarcated roads with barriers. Figure 8, for example, shows the participant's ideas about how to improve safety on their Town Camp. There are bollards surrounding the road into the Town Camp, a children's playground in the centre, and green areas for people to meet. Each house has its own fenced in yard and garden.

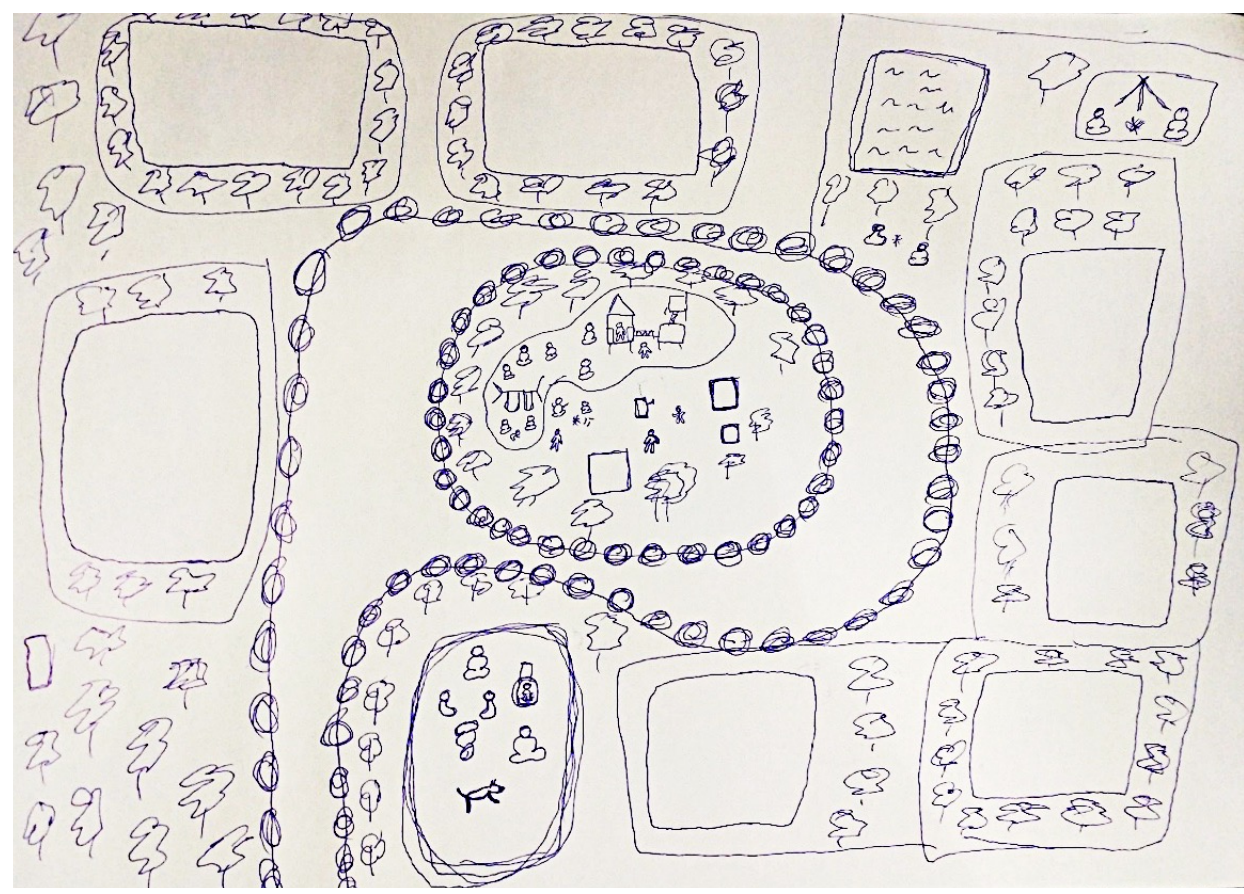

Figure 8. A participant's drawing of a safe Town Camp

The Canadian Journal of Action Research, Volume 21, Issue 3 (2021), 52-71 
Similarly, Figure 9 shows a participant's vision for their Town Camp's safety. The road into the Town Camp is fenced, and each house has secure yard. At the centre of the Town Camp is the community centre. What is evident in the drawings is that participants consider safety by environmental design to be important and that improved infrastructure was vital to increasing safety on Town Camps.

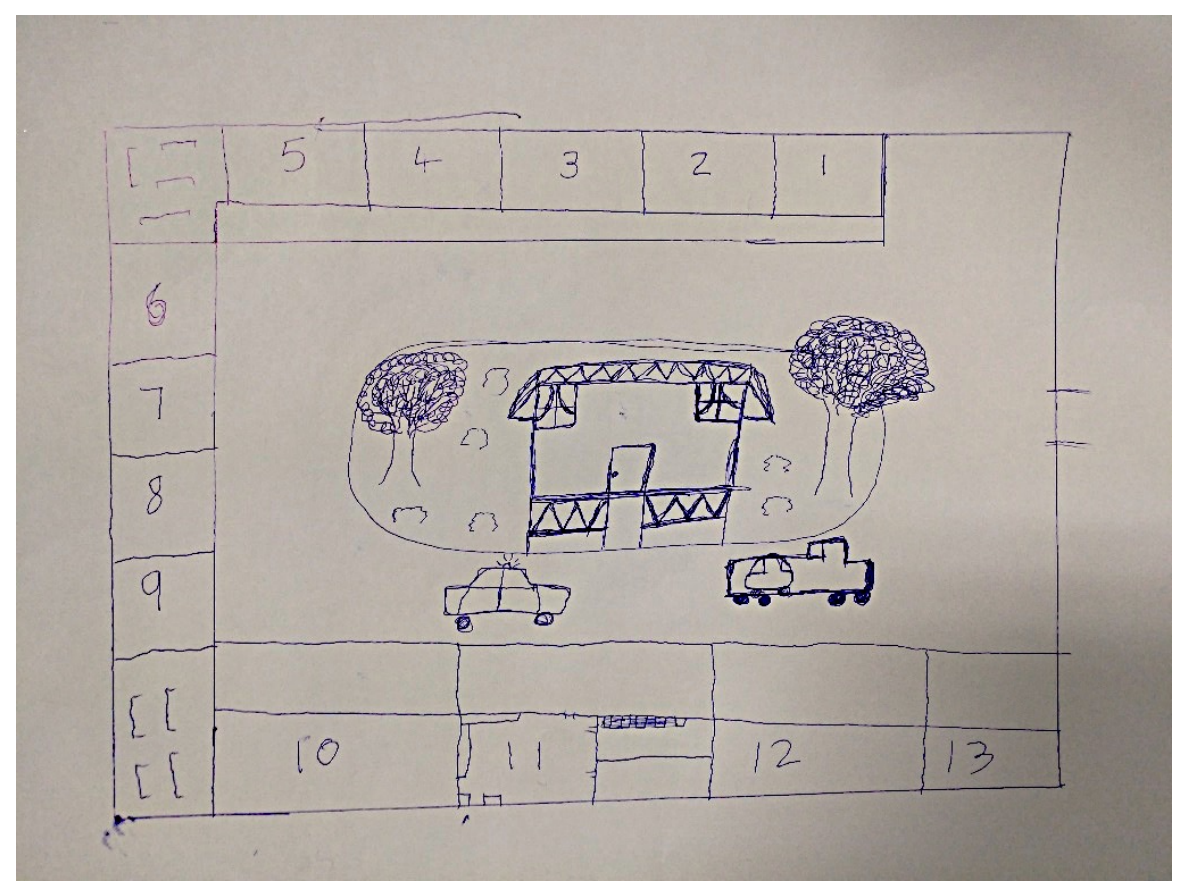

Figure 9. A second participant's drawing of a safe Town Camp

After each participant presented their drawing, and a discussion followed about what a safe place was, what it looked like and what it needed. The group then produced a joint piece (Figure 10) illustrating what is needed for safety within Mparntwe/Alice Springs: all the community needs to be involved, everyone working together, keeping a watchful eye for each other, and regular community meetings to discuss any problems. There are community safety hubs and safe schools for children.

The drawings were useful as again it provided a means for participants to share their ideas and knowledge, especially participants with limited English. Moreover, in a focus group, sometimes particular voices can dominate - the maps and the drawings allowed each participant to convey their views, without necessarily having to 'hold the floor' in front of others. Most importantly, the maps and drawings allowed 'marginalised voices' to be accessed. Aboriginal women from Town Camps in Mparntwe/Alice Springs were able to share their knowledge and expertise to inform safety planning in their communities. 


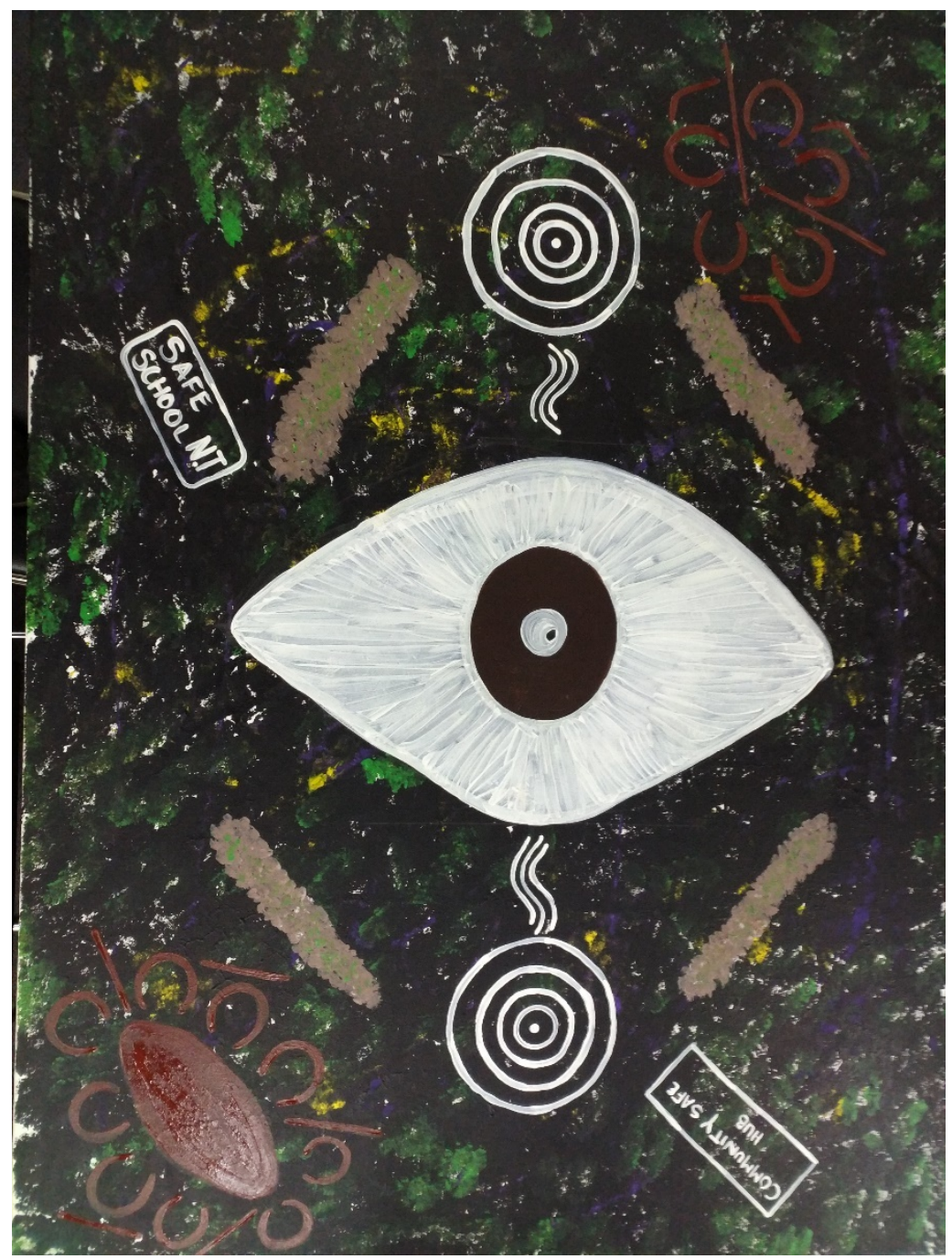

Figure 10. Painting showing what is needed to improve safety in Mparntwe

\section{INDIGENIST PARTICIPATORY ACTION RESEARCH}

Indigenous methodology is one way of 'writing back' against colonial narratives which pathologize Indigenous people. It challenges the power dynamics between the researcher and the researched, which has historically been an exploitative relationship between researchers and Indigenous peoples (Aveling, 2013; Martin, 2006; Smith, 1999). Exploitative research has been used to legitimize colonization (Ball \& Janyst, 2008; Cochran, et al., 2008; Martin \& Mirraboopa, 2009; Smith, 1999; West, Stewart, \& Foster, 2012). Researchers regularly made Indigenous peoples the subject of their research, who they categorised as sub-human, which legitimized the violence committed against them (Cochran, et al., 2008; Martin, 2006; Smith, 1999; West, Stewart, \& Foster, 2012). Researchers also extracted songs, stories, language and other forms of knowledge, then distorted them in their reproduction (Ball \& Janyst, 2008; Kite \& Davy, 2015; Martin, 2006). Such research served to benefit the colonizers, rather than Indigenous people. On the other hand, Indigenist methodology seeks to redress the power imbalance between the researcher and Indigenous people and empower Indigenous people by decolonizing research methodologies. Indigenous 
methodology positions Indigenous people as partners and decision-makers in research (Cochran, et al., 2008; Kite \& Davy, 2015; Martin, 2006; West, Stewart, \& Foster, 2012).

Safety mapping is an example of symbiotic convergence of Indigenist methodology and action research. Safety mapping used participatory action research to empower participants with an evidence-base from which to create change and advocate for social justice. The safety mapping was an example of Indigenist research because it was underpinned by seven key principles. First, the safety mapping was contextualized within the historical context of colonization through a discussion about the history of Town Camps and the impacts of colonization on these communities (Ball \& Janyst, 2008; Smith, 1999). Second, the safety mapping was specifically aimed at fostering self-determination and restorative social justice (Ball \& Janyst, 2008; Kite \& Davy, 2015; Rigney, 2006; West, Stewart, \& Foster, 2012). The safety mapping was grounded in the knowledge that Town Campers have the expertise to solve the problems that affect them, many of which were created by a history of successive government policies. Safety mapping aimed to address social justice issues on Town Camps by developing knowledge products that were owned by and beneficial for Aboriginal people. Third, the safety mapping privileged the voices of Indigenous people by centring their perspectives and experiences (Kite \& Davy, 2015; Rigney, 2006; Smith, 1999; West, Stewart, \& Foster, 2012).

Fourth, the safety mapping was grounded in Indigenous epistemology and ontology by working in a culturally safe way, or what we called 'working in a good way', for Aboriginal people (Aveling, 2013; Cochran, et al., 2008; Martin \& Mirraboopa, 2009; Rigney, 2006). This meant the use of culturally appropriate methods that allowed for a range of different voices to be heard, conducted in a culturally safe physical environment. Some safety mapping sessions were held outside with all participants sitting in a circle on the ground, while other sessions were held inside the community centre around art tables as participants painted. Working in a good way also meant that I travelled to where people were, taking food, sitting down and yarning. The emphasis was on listening rather than asking a list of questions. Deep listening was crucial to safety mapping, as sometimes a researcher cannot even know the right questions to ask or how to ask them. I understood that some participants might participate a little, perhaps leave part way through, or come late, and that perhaps not all questions would be answered, or they would be answered in a different way. I also had to learn to use silence and to sit with silence, and instead of trying to fill silences with talking or more questions, to wait and listen to the response. It was also about people communicating their knowledge in different ways: through gesture (Aboriginal sign language); through art or drawing; through another participant translating; being shown; being told a story; some people chose to simply sit and listen. This ensured participants felt comfortable - the environment was familiar, relaxed, and informal. Safety mapping positioned Town Campers as research partners and as experts, so Indigenous ways of knowing, being and doing were centred.

Fifth, the safety mapping was done in partnership with Indigenous people (Ball \& Janyst, 2008; Martin, 2006; Rigney, 2006; Smith, 1999; West, Stewart, \& Foster, 2012). I presented different ideas and asked Town Campers and allies what was most appropriate, what kind of questions should be asked, how many questions, and how they should be phrased. Rather 
than focus on being able to generalize findings, the focus was on the method and approach being right for each participating Town Camp or group.

Sixth, the safety mapping was done with the explicit aim of being relevant and beneficial to Aboriginal people (Ball \& Janyst, 2008; Cochran, et al., 2008; Rigney, 2006; Smith, 1999). Finally, throughout the safety mapping, Aboriginal people were consulted about the dissemination of the findings and to ensure that Aboriginal people maintain control over their own cultural knowledge (Rigney, 2006; Smith, 1999; West, Stewart, \& Foster, 2012). I recorded each safety mapping session using handwritten notes. At the end of each safety mapping session, I would read back over my notes to check their accuracy. This became a strength of the method as this often led to more discussion. I then typed up the transcript and sent it back to the community centres for checking. This provided the participants with two opportunities to correct me and/or to have further discussion. It also reaffirmed consent and offered another level of transparency. Once the report was finalized, it was printed and returned to participating Town Camps, where I also discussed the findings and what would happen with the report. Tangentyere Council retains ownership over this report and the data.

The safety mapping engaged with Town Campers as 'co-researchers' to research their own communities in order to identify safety issues and present solutions. The safety mapping provided a forum in which the voices and knowledge of Town Campers were engaged in research efforts, rather than as subjects of research. The safety mapping took an Indigenist approach to action research that was relevant and contextually appropriate, and that built upon community relationships and culture to present Town Camper's ideas about how to improve safety.

\section{FINDINGS}

In the safety mapping, Town Campers identified five main safety issues within Town Camps and presented solutions to improve safety. These five issues were identified through a thematic analysis ${ }^{6}$, so although more issues were talked about in the safety mapping, these were the issues that were common across all participating Town Camps. The key safety issues were: visitors, violence, road safety, phones, and parks and open spaces. To each of these issues, Town Campers suggested solutions appropriate to their place and context. All the solutions proposed by Town Campers fall into three broad categories: improved facilities and infrastructure, education and training for Town Campers, and improved relationships with services. These solutions were reflected in the places identified as 'safe' by Town Campers, as they mirrored these themes: these were sometimes places that were made physically safe through environmental design, but mostly it was the people that made a place safe. Each of the issues and corresponding solutions are discussed below, then the safe places identified in the safety mapping are outlined.

\footnotetext{
${ }^{6}$ All the transcripts were then compiled into files using NVivo software. I used NVivo to code words, phrases, sentences, and whole files according to their themes.
} 
The safety concern overwhelmingly highlighted by Town Campers in the safety mapping was visitors. 'Visitors' is used to refer to family ${ }^{7}$ who travel into Mparntwe/Alice Springs from remote Aboriginal communities. Usually, visitors travel into town to do food shopping and access goods and services, which are largely unavailable in remote communities. Some visitors also travel in to see family and experience life in the regional town, sometimes wanting to access alcohol which is prohibited in remote Aboriginal communities ${ }^{8}$. When in town, visitors will usually stay with family in Town Camps, and will sometimes become stuck due to lack of funds or because they simply want to stay in town longer. As a result, visitors often end up staying in Town Camps for months at a time, and this contributes to overcrowding and food insecurity. Town Campers also linked visitors to drinking, violence and road safety problems.

"Some [visitors] come here for shopping, and get stuck from drinking, and then houses are overcrowded, then there's fighting." [SM9]

"When visitors go home, everyone is relaxed, everyone has food. But when it's crowded, everyone is tired, there's violence, and there's not enough food. You can see the difference immediately, when it's not crowded, kids are sleeping, kids are going to school, there's enough food." [IS10]

It was clear that participating Town Campers wanted some form of visitor control and proposed a myriad of solutions, including imposing a permit system, a two-week maximum stay for visitors, and the use of swipe cards to enter Town Camps.

Town Campers also spoke extensively about the problem of violence in Town Camps. Town Campers often linked violence with visitors and drinking. This was because participating Town Campers believed that many visitors come into town to drink, which meant they stayed longer, and triggered violence.

"Fights start when people are drinking." [SM11]

"Put something up and say you can't be here and do that, not all day and night.

Visitors bring a lot of other people. There's so many people drinking and having fights." [SM37]

Town Campers also referred to 'family fighting' and 'noisy houses' where there was always 'arguing', and these were references to family and domestic violence. Town Campers talked about the severity of this violence, and how community members would intervene in these fights by calling the police. The stories showed how violence came to affect the whole community, as Town Campers regularly witnessed family and domestic violence. Town Campers also raised other types of violence, including between families, communities, and inter-camp conflict. Two participating Town Camps raised the inter-camp conflict between

\footnotetext{
7 This includes extended family and connections through kinship

${ }^{8}$ It is also illegal to possess or consume alcohol on Town Camps, which are prescribed zones under the Northern Territory Emergency Response (2007), however this is much more difficult to monitor and enforce in Town Camps than it is in remote communities. This is because of Town Camps' proximity to bottle shops and licenced venues, and it is easy to get alcohol into Town Camps through the use of back roads or even regular traffic. Because people are constantly traveling in and out of Town Camps, it is difficult to police the influx of alcohol.
} 
them as being of great concern. This conflict was large scale and multi-site, often occurring in different parts of the town and involving many families, contributing to a culture of fear in those camps (this conflict is currently in mediation). The issue of reprisal violence was also raised by Town Campers as a safety issue as they knew that one violent incident could lead to future lateral violence.

"It's about the bigger picture, they just think it's just fighting, but if people get stabbed or someone gets murdered, people will come from out bush and family will be coming. What will people say then? We'll be terrified for the rest of our lives." [SM37] "Noise. Argument. They fight [identifying house on the map]." [SM25]

Town Campers said they regularly called the police when violent incidents arose, but that they weren't always happy with police response, which they felt took too long and involved answering too many questions when they dialled emergency numbers. However, given the history of policing in Aboriginal communities (Allam, Wahlquist, Banister, \& Herbert, 2019; Brown, 2014; Schubert, 2018), this is a positive change and important finding that Town Campers feel safe enough to seek a service from police.

"No. It's not safe there. I've seen women getting half killed [on oval], I have to call the police." [TWFSG8]

"Police come. Visitors come. And they make noise. Arguments and fights. We call the police straight away." [SM25]

Town Campers again proposed solutions for to the problem of violence, such as visitor control, mediation, and domestic and family violence training. Town Campers also suggested that the response from police could be bettered by improved police-community relationships and communication.

Another safety issue raised by Town Campers was road safety. Town Campers fears about speeding, the use of informal roads, and drunk driving were linked to their fears about safety for their children. Town Camps do not have footpaths, so most people, including children, walk on the sealed roads. People also often use trails through the bush to reach different parts of their camp. Town Campers talked about how children like to play on roundabouts, traffic islands, and in other open spaces. Children walk freely around Town Camps to visit family and friends, so Town Campers considered road safety to be of vital importance. Town Campers often talked about speeding through the camp (which was again linked to visitors), and cars doing burnouts (usually referred to as 'spinning') in the open spaces, and they feared someone would be injured. Town Campers talked about how informal dirt roads were used to access Town Camps and to cut through different parts of the camp, which they feared put the children using open spaces at risk.

"It's not good hey? Need a speed bump, not safe for kids to play at the playground. Youngsters not safe here." [SM10]

"Too much cars going past. Kids run around the road. It's dangerous with cars." [SM14] 
To address their concerns about road safety, Town Campers suggested instalment of speed bumps, road safety signs, and footpaths. They also suggested the instalment of bollards to prevent people from driving off-road or accessing Town Camps through back roads. To further improve safety, Town Campers also suggested improved street lighting which they believed would improve road safety.

Phones were also raised as a safety issue by Town Campers. On all participating Town Camps, only one had a working payphone located in a safe area. In the other participating Town Camps, public payphones were either broken, located in unsafe areas, or were too far away. Town Campers said that this meant they would have to leave their homes and travel into an unsafe area, usually where large groups of people were gathered to access blackmarket sales of alcohol, to call for help. Town Campers also often talked about how payphones were damaged in attempt to prevent people using the phone to call police. Town Campers regarded access to public payphones as vital to safety because many Town Campers have no access to a mobile phone, or credit to make phone calls, or the digital literacy required to use a phone - this concern was particularly raised in reference to the elderly and sick people. The damaged or inappropriately located phones therefore placed further obstacles to Town Campers help-seeking. Town Campers also raised that some people did not know who to call for help so people needed to know about what support services were available to them.

"Yeah, two [phones]. But not working properly...Can't use them to call police or ambulance... No [phones are not in safe places]. There's too many people around there." [SM13]

"[Pointing to houses on opposite of community centre] These are family houses, they have phone. Can ring up the police if there's fight going on. Some people, they don't know how to use a phone, or they don't have a phone." [SM3]

Town Campers once again proposed multiple solutions to their concerns about phones. They suggested that all Town Camps have public coin-operated payphones installed in multiple well-lit locations, and that these be regularly serviced. Many Town Campers suggested that a payphone be placed at the community centres. Town Campers also proposed that payphones be housed in protective cages to prevent damage, and possibly locked, with keys left in the hands of trusted community members. One camp suggested that designated safety people be given mobile phones preloaded with contact numbers for safety services. These people could be accessed in times of danger to call for help on behalf of other Town Campers. Several participants also suggested that mobile phone charging stations and emergency buttons be installed in parks or on light poles, to further help Town Campers call for help.

The fifth main safety concern identified in the safety mapping was parks and open spaces. Town Campers felt parks were important for Town Camps and said that children made regular use of them, but they were concerned that these were unfenced, and danger was posed to the children by cars on nearby roads. Town Campers also said open spaces on camps were unsafe, as during the day, these spaces would be used for 'spinning', and these places were also typically very dark at night, and people would often congregate there to 
drink. Visitors would also often camp in these open spaces. Town Campers often talked about the violence that would occur in open spaces.

"They use [the oval] as a recreation park, as a fighting ground." [TWFSG8]

"Kids feel safe in the park so they play there until late at night but they need better lighting

there. Parks are central to all the houses here but need a phone or emergency button in them." [SM41]

To address their concerns about parks and open spaces, Town Campers suggested the introduction of key safety features which would improve safety through environmental design. Town Campers suggested that parks be fenced, and emergency buttons be installed so children could call for help. Town Campers suggested that open spaces could be used in a better way by converting them into parks and playgrounds. They proposed that lighting be introduced and/or improved in all these spaces. It was clear that Town Campers valued parks and that they were made use of frequently, but open spaces could be used in better ways, and all parks and open spaces needed to incorporate safety features.

In addition to identifying safety issues on their Town Camps, participants identified safe places and safe relationships. Overwhelmingly, Town Campers identified the community centre, hospital, women's shelter and family homes as being safe places. Some participants, however, did say that the only place they felt safe was their own home.

When asked what made these places safe, Town Campers identified some safety features such as lockable doors and windows, a fence, a gate and lighting. However, what was most common in their answers was that it was generally people that made a place safe - these could be family members, workers, or security. The hospital, for example, was often identified as a safe place because of the presence of security guards. The community centres were identified as safe because they had fences, phones, and food, but also because people gathered there to meet or paint, and the centres have culturally safe staff. Family homes were identified as safe because although the house itself may lack safety features, family members were there who could help.

"People [make places safe]. People we're comfortable around. Lock the door if you're alone, but still feel panicking, 'cause people can force their way through, especially If there's a group." [SM37]

"Cause we got a lot of family surrounding, that'll make us safe." [SM23]

"Numbers. In the numbers, makes kids safe. It's always 5, 6, or 7 of them. Safety in numbers. Same with adults, even drinking mob, you'll see them moving around in groups, that's their safety as well." [SP7]

"Hospital is safe. All them security." [SM6]

When discussing who they could call if they ever felt unsafe, Town Campers identified safe services and relationships that could be drawn upon. These services included the women's shelter, the two youth centres in Alice Springs, Tangentyere Council, and emergency services, 
including police 9 . A range of other services were identified, but what was common among them all was that these were known trusted and approachable services with culturally safe staff - Town Campers felt they could rely on these services. Town Campers said it was important for Town Campers to know and be aware about what services were on offer and how to access them. They proposed that Town Campers be given training and that these services be advertised on Town Camps. Town Campers also suggested that these services improve their relationships with Town Campers by spending more time on Town Camps and talking with people. Town Campers felt this would improve safety by making it more likely that Town Campers would seek help from these services in dangerous situations, and would discourage visitors and loitering as police in particular would know who was a resident of a Town Camp and who was not.

"Call the police from a safe place." [SM16]

"Some people come to us for help, to call the police, or the ambulance, this is a safe place." [SM5]

The five main safety issues identified by Town Campers illustrate that they are aware of the issues on their Town Camps and already have the solutions to solve these problems. Town Campers mapped out these solutions and proposed locations, facilities, and features which would improve safety on Town Camps. Town Campers also identified safe places and services which can be drawn upon for help and support. The safety mapping shows that it is primarily people and relationships, rather than bricks and mortar, that make a place safe. The safety mapping reflected that Town Campers are the experts on the issues that affect them and their Town Camp.

\section{CONCLUSION}

The safety mapping sought to uphold Indigenous voices by driving action research with the expertise and perspectives of Town Campers. The safety mapping valued and centred the experiences of Aboriginal people, whose voices have historically been marginalised by mainstream Australia. In response to deficit-based methods, the safety mapping took a strengths-based approach to harness the wealth of knowledge in Town Camps and work in partnership to develop solutions to problems that affect Town Campers. By identifying safe places, the safety mapping sought to empower Town Campers by collating their knowledge and disseminating knowledge products that could be used for advocacy purposes. Since the release of the report, Tangentyere Council has drawn upon the safety mapping in funding and grant applications, as well as to continue to advocate for Town Campers. The safety mapping project was ultimately accountable to Town Camp communities and reported the findings and outcomes back to participants and community centres. In this way, the safety mapping sought to benefit Town Campers by knowledge gathering and sharing in a transparent and participatory process, with the ownership of this knowledge remaining with Aboriginal people. The safety mapping findings emphasise how important it is to deeply

\footnotetext{
${ }^{9}$ The safety mapping was conducted in April of 2019, after this time there was the shooting death of Kumanjayi Walker by a police officer at a nearby remote Aboriginal community (Allam, Kumanjayi Walker: NT police officer charged with Yuendumu murder suspended on pay, 2019). This could possibly impact upon Town Campers feelings of safety about police.
} 
listen to Indigenous people. The safety mapping shows that Indigenous people should not just be included in research and decision-making - they should be at the forefront.

\section{REFERENCES}

Allam, L. (2019, November 14). Kumanjayi Walker: NT police officer charged with Yuendumu murder suspended on pay. The Guardian. shorturl.at/kpX34

Allam, L., Wahlquist, C., Banister, J., \& Herbert, M. (2019, August 24). Deaths inside. Deaths Inside Indigenous Australian Deaths in Custody. https://www.theguardian.com/ australia-news/ng-interactive/2018/aug/28/deaths-inside-indigenous-australiandeaths-in-custody

Aveling, N. (2013). Don't talk about what you don't know': On (not) conducting research with/in Indigenous contexts. Murdoch University Repository. http://researchr epository.murdoch.edu.au/11141/1/Author_copy_Don\%C2\%B9t_talk_about_2.pdf

Ball, J., \& Janyst, P. (2008). Enacting research ethics in partnerships with Indigenous communities in Canada: "Do it in a good way". Journal of Empirical Research on Human Research Ethics, 3(2), 33-51.

Brown, C. (2014). 'Splitting ourselves down the middle': The impact of the Northern Territory Emergency Response on violence against Indigenous women in Alice Springs' Town Camps. Alice Springs, Australia. Doi: 10.13140/RG.2.1.4554.3925.

Brown, C. (2019). Where are the safe places? Safety mapping with Town Campers in Alice Springs. Canberra, Australia. Doi:10.25911/5df8a0dfe3f6d. Commissioned Report no. 3, Centre for Aboriginal Economic Policy Research, Australian National University.

Cochran, P.A., Marshall, C.A., Garcia-Downing, C., Kendall,E., Cook, D., McCubbin, L., \& Gover, R.M. (2008). Indigenous ways of knowing: Implications for participatory research and community. American Journal of Public Health, 98(1), 22-27.

Criminal Justice Research and Statistics Unit. (2017). Northern territory correctional services and youth justice annual statistics 2015-2016. Darwin: Northern Territory of Australia, Department of the Attorney-General and Justice.

Department of Attorney-General and Justice. (2018). Northern territory crime statistics data through June 2018. Darwin: Department of Attorney-General and Justice, Northern Territory Government .

Foster, D., Mitchell, J., Ulrik, J., \& Williams, R. (2005). Population and Mobility in the Town Camps of Alice Springs. Alice Springs: Tangentyere Council Research Unit. Knowledge Cooperative Research Centre.

Kite, E., \& Davy, C. (2015). Using Indigenist and Indigenous methodologies to connect to deeper understandings of Aboriginal and Torres Strait Islander peoples' quality of life. Health Promotion Journal of Australia 26, 191-194. 
Martin, K. (2006). Please knock before you enter: An investigation of how rainforest Aboriginal people regulate outsiders and the implications for western research and researchers. PhD thesis. James Cook University.

Martin, K., \& Mirraboopa, B. (2009). Ways of knowing, being and doing: A theoretical framework and methods for Indigenous and Indigenist re-search. Journal of Australian Studies, 27(76), 203-214.

Rigney, L. (2006). Indigenist research and Aboriginal Australia. In J. Kunnie \& N.I. Goduka (Eds.), Indigenous Peoples' Wisdom and Power: Affirming Our Knowledge Through Narratives (pp. 32-50). Bodmin, U.K.: Ashgate Publishing Limited.

Schubert, S. (2018, August 25). Coniston Massacre: NT police apologise for state-sanctioned massacre of Aboriginal people. ABC News. https://www.abc.net.au/news/2018-0824/nt-police-apologise-for-state-sanctioned-coniston-massacre/10162850

Smith, L.T. (1999). Decolonising methodologies: Research and Indigenous peoples. London: Zed Books.

Tangentyere Council. (2008). Tangentyere Council Aboriginal Corporation. Historical Overview. https://www.tangentyere.org.au/about/background/index.html\#top

West, R., Stewart, L., \& Foster, K. (2012). Through a critical lens: Indigenist research and the Dadirri method. Qualitative health research, SAGE Publications.

\section{BIOGRAPHICAL NOTE:}

Chay Brown is from Mparntwe/Alice Springs in the Northern Territory. Chay is a PhD Scholar with the Centre for Aboriginal Economic Policy Research at the Australian National University. She has been researching violence against Indigenous women for six years, and has lived experience of domestic, family, and sexual violence. She completed her Master's research on the impact of the Northern Territory Emergency Response on violence against women in Alice Springs' town camps. She has led safety mapping exercises with women in town camps in Alice Springs; and has led a series of workshops throughout the Northern Territory to deliver specialist domestic, family, and sexual violence training and to develop a Northern Territory specific violence prevention framework.

Chay also has eight years of experience working with children and families who experience/have experienced violence. Chay has also previously worked in antitrafficking, working alongside women in safe houses who had survived sex trafficking. Chay has a background in International Development and Education. She has previously been involved in projects in HIV testing and counselling, micro-financed incomegenerating projects and teaching colleges. She has previously worked in East Timor, Uganda, U.K., Thailand and China. She currently lives in Mparntwe/Alice Springs, Australia. 